\title{
Poverty Reduction Programme in Nigeria: An Assessment of its Implementation in Enugu State
}

OMEMMA, Dilichukwu A. || OKAFOR, Chukwuemeka

\section{Abstract}

$\mathrm{T}$ he study has as its main thrust the evaluation of the implementation of the national poverty reduction programme in Enugu State of Nigeria. Using crosssectional and exploratory methods of data collection and analysis, the study discovered that, compared to most states in other parts of the country, Enugu State has a low poverty profile owing to the relative positive impact of the implementation of poverty alleviation programme. Nevertheless, policy inconsistency and mismanagement deny the programme from becoming a total success; hence the existence of a larger number of citizens that are in absolute poverty. It is therefore suggested that the way out of the ineffective poverty reduction programme in Enugu State is the effective monitoring mechanism and the creation of an enabling environment for wealth creation and employment generation.

Keywords: Poverty Alleviation, Poverty, Mismanagement, Programme, Implementation, Nigeria

VOLUME 2 (1) 2014

\section{AFRICA'S PUBLIC SERVICE DELIVERY AND PERFORMANCE REVIEW ISSN 2310-2195 (print) ISSN 2310-2152 (online)

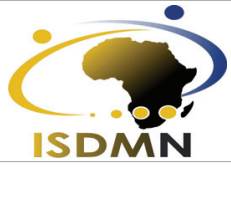 ISDMN}


70 Africa's Public Service Delivery \& Performance Review

\section{Introduction}

When in 2003, the government of Chief Olusegun Obasanjo launched the poverty alleviation programme, the poor in Nigeria who constitute about $70 \%$ percent of the estimated total population of about 140 million based on the 2006 census heaved a sigh of relief that their condition of extreme poverty would soon be a thing of the past. Ten years after the launching of this grandiose programme, the proportion of Nigerians groaning under the yoke of poverty seems to be increasing every year. According to the 2010 Nigerian Poverty Profile Report released on February 13, 2012 by the National Bureau of Statistics, in terms of both relative and absolute measurements, poverty in Nigeria has been on the increase since 2004 - one year after the birth of the poverty alleviation programme (The Report of National Bureau of Statistics 2012 2-3).

For instance, the 54.7 percent of Nigerians found to be living in poverty in 2004 snowballed into 69 percent or 112,518,507 Nigerians in 2010. The breakdown of this poverty index according to the Report indicates that in terms of relative poverty, Nigeria's poverty measurement stood at 69 percent. In terms of absolute poverty, $60.9 \%$ or $99,284,512$ Nigerians were affected. In terms of dollar per-day measurement, $70.4 \%$ of Nigerians were involved, while 93.9 percent of Nigerians considered themselves to be poor in terms of subjective poverty measurement. If this scary picture represents the 2010 poverty index of Nigerians, the 2011 poverty index of Nigerians which stood at 71.5 percent is a sheer indication that all efforts aimed at poverty reduction by the various stakeholders in Nigeria might have been a drop in the ocean. In Enugu State of Nigeria for instance, majority of the citizens in both relative and absolute terms, belong to the category of the poor whose income earning capacity makes it impossible for them to afford the basic needs of life such as food, basic education, shelter, good medication, and health facilities.

The disturbing trend resonated the concern of the former Governor of the Central Bank of Nigeria, Prof. Chukwuma Soludo who in 2008 acknowledged the ravaging presence of poverty in Nigeria when he declared that "poverty is unacceptably high in Nigeria but the alarming and persistence level of poverty is a phenomenon in the North" (Newswatch 2012: 13). Many attributed this development to poor leadership. For instance, while attempting a prognosis of Nigeria's poverty situation, Utomi (2012:57) pointed at the defective leadership and the corruption at the high level. He argued that 
public policy in Nigeria is not poor-friendly and often without meaning to do it, moves to deepen poverty. In the same vein Olowu (2012:57) stressed that when people are not employed and are not given money to be able to be part of the economic activities, then it will create a systemic collapse of the economy.

The implication of the above views is that the persistence of poverty in Nigeria is linked to graft and misapplication of fund. This stems from the occasional doling out of free funds to a selected community of the poor at the expense of the larger groups when tackling the poverty phenomenon (Odunuga 2012:67). In view of these, the article therefore focuses on assessing the implementation of poverty alleviation programme in Enugu State. The work is divided into the following sections: section one is the introduction, section two discusses contending perspectives on poverty, section three focuses on the incidences of poverty in Nigeria, section four assesses the implementation of the national poverty alleviation programme Enugu State, while section five is the conclusion.

\section{Dominant perspectives on poverty}

Poverty like most phenomena in the social sciences has been ascribed different meanings depending on the ideological persuasion of the analysts or the conventions of the society in which it occurs (Eric 1968: 398). Thus, it is like beauty which lies in the eyes of the beholder. Nevertheless, as Sen (1981: vii) rightly observed, based on its biting effects, one does not need elaborate criteria, cunning measurement, or probing analysis to recognize raw poverty, and to understand its antecedents. Therefore, there is a consensus on the existence of poverty world over. But what is not obvious enough and is indeed generating controversy is the cause of poverty. Consequently, just as there is a plethora of commentaries on the incidences of poverty in Nigeria so is there a deluge of perspectives on the driving forces of the phenomenon. In this study, two dominant perspectives have been identified for discussion. They are the liberal and the radical perspectives. 
72 Africa's Public Service Delivery \& Performance Review

\section{i. The liberal perspective:}

The thrust of this view, popular among the government and agents of the status quo, is that poverty is natural and should be condoned as divine because man prospers only according to the will of God (Calvin 1509-64). In other words, the proponents of this view contend that the prosperity of some persons is not only a clear sign that God has chosen them for salvation, but also that all fingers are not equal. As such everybody is not created with equal skill and talent. Thus, those with rational insight and ingenuity are created to be rich and those bereft of these essential attributes are created to be poor and depend on the philanthropy of the haves. Accordingly, life is all about survival of the fittest and the elimination of the unfit. The basic assumption of this view is that everyone has an equal opportunity to show how unequal he/she is and that it is only the fittest that must make it in the struggle for existence in this Hobbesian war of every man with every group against every man with the other group (Hobbes 1651 in Appadorai 2003: 22).

The liberalists are therefore opposed to poverty alleviation and insist that the state should do nothing to relieve the condition of the poor who are assumed to be the less fit. In the words of Spencer (1940):

Welfare scheme were to be restricted because they reward unfitness. The welfare schemes to be championed are those that speed up the elimination race. All that the unfit should expect was charity not entitlement or benefit.

A variant of the liberalist doctrine expounded mostly but not exclusively by the political elites and agents of government is that the poor are poor because they are lazy. In other words, they blame the poor for not working hard enough to liberate themselves from the poverty trap. They therefore refuse to accept responsibility for poverty in Nigeria and instead shift the blame to the individuals or market forces. Based on this viewpoint, poverty alleviation is merely motivated by government compassion and charity and most importantly to avoid embarrassment because:

People must not be allowed to become so poor that they offend or are hurtful to society. It is not so much the misery and plight of the poor but the discomfort and cost to the community which is crucial 
to this view of poverty. We have a problem of poverty to the extent that low income created problems for those who are not poor (Rein, 1971: 13).

Other liberal thinkers that share the blame-the-victim tendency blame poverty on the attitude and psychological defeatism of the poor who passively accept their situation and willingly accord unequal position to those who are generally admired and believed to be superior (Lampman 1961:34; Jouvenal 1951:84). None of the variant of the liberalist perspective is appropriate and sufficient to explain the incidence of poverty, thereby justifying the irrelevance of the poverty alleviation programme. This is simply because government is a necessary instrument for maximizing individual opportunity and rights, especially of those citizens who are prevented by circumstances beyond their control from beginning the footrace of life from the starting line. Therefore, it is misleading to regard the programme of poverty alleviation as an act of compassion or charity, just as it is also erroneous to see it as being induced by the fear of embarrassment. Poverty reduction should instead be seen as an obligation of a responsive and responsible government. The unpopularity of the liberalist doctrine makes it to be clearly in the minority and, therefore, justifies the impetus to turn to its alternative - the radical perspective.

\section{ii. The radical perspective:}

The thrust of this argument is that God created every person equal, but man creates inequality in the society. Thus, according to the proponents of this view, poverty is not ordained by God but is imposed by man. They therefore, attribute poverty to the various policies and tendencies of government and the rich to block and deprive the opportunities of the weak and the defenceless. According to Lampam (1961:34) such policies that promote and sustain poverty and inequality in the society include:

i. law of inheritance,

ii. the practice of nepotism,

iii. class favouritism,

iv. gender discrimination,

v. restriction of educational opportunity, and 
74 Africa's Public Service Delivery \& Performance Review

vi. unequal distribution of sanitation and health protection.

According to Marx (1977: 20-22) poverty is a product of exploitation by the bourgeoisie, backed by the state. Accordingly, poverty and affluence are different sides of the same coin. In other words, what makes one rich is what makes the other poor. Thus, exploitation and oppression are responsible for the existence of poverty in the society. Based on this radical standpoint, poverty in Nigeria is blamed on the government and the comprador bourgeoisie whose policies and activities create and perpetuate poverty and widen the gap between the haves and the have-nots. Utomi cited in Newswatch (2012:57) explains that why Nigeria has remained entrapped in poverty is because of defective leadership and the corruption at the highest level. In his exact words:

How can you explain.....a situation where we have a presidential fleet of airplanes that is bigger than most airlines in the country except possibly Arik Air. What do they do with these planes? Girl friends are flying all over the places, official assignments, whatever those are. Do you also know you can project how many children will not live to be five years old because of that next presidential jet that is being ordered?

He therefore concluded that public policy in Nigeria is not pro-poor as it often moves to deepen poverty. Thus, the subscribers to this view are convinced that the poverty situation in Nigeria cannot be reversed except if corruption and mismanagement of resources by the leaders are decisively dealt with. Poverty alleviation programme for them is illusory and groundless going by the incessant imposition of anti-poverty alleviation policies such as the demolition of illegal structures, abolition of commercial motor-cycle operation in the urban areas, imposition of arbitrary revenues on small-scale business outfits as well as the attachment of stringent hire-purchase terms to the tricycles offered by the government to alleviate poverty. This, to the radical view, amounts to creating poverty with poverty alleviation programmes and justifies the assumption that the poverty alleviation programme in Nigeria is a façade to justify the anti-people policies of government and dupe the masses into compliance. This is therefore, a sheer contradiction of the poverty alleviation programme since the majority of Nigerians earn 
their living through small-scale enterprises that mostly thrive by the roadside kiosks and containers which are within the means of the poor.

\section{The trends and dynamics of poverty in Nigeria}

Perhaps it is difficult to trace the origin of poverty in Nigeria. But most studies have the consensus that the present poverty profile of Nigeria was given impetus by the Structural Adjustment Programme (SAP) of the mid-1980 (Agbu 2008:72; Sautter, 1990:7 Sunmonu 1990:8 \& Toyo 1989: 20). The prevailing depressed economy then had compelled the military government of General Ibrahim Babangida ( $r \mathrm{td}$ ) based on the prescription of the International Monetary Fund (IMF) and the World Bank to adopt the Structural Adjustment Programme (SAP) as a panacea. Integral to the programme include but are not limited to:

i. Devaluation of the currency,

ii. trade liberalization,

iii. a cut in public sector expenditure which involves retrenchment of labour in the public sector,

iv. the privatization of the public sector enterprises which were set up to promote development,

v. curtailment of government subsidies (including protection of individuals) and

vi. the raising of interest rates (Toyo, 1989:20-21).

This straight-to-rule application of the prescriptions resulted in the collapse of local industries (as they could not compete with their foreign counterparts that were liberalized), sale of public sector, weakening of the naira resulted in the retrenchment and retirement of the workforce from the public sector. The overall consequence of these measures include unemployment resulting from the massive reduction of over two million workforce from the public sector and the loss of about 40,000 workers of over seventy companies that were forced to shut down in the wake of the liberalization, decrease in social spending in the area of education, health, housing, water, energy, transportation following the withdrawal of government subsidies, and ultimately the 
aggravation of poverty in Nigeria (Sunmonu 1990:8; Agbu 1997:80-81). The multiplier effect is that both school leavers and graduates of higher institutions could not secure jobs just as those still in school or about to start school were forced to withdraw their ambition of acquiring education because of the drastic reduction of funding to education to 30 per cent (Onuoha, 1995:53 cited in Agbu, 1997:80-81).

Ever since the adoption of this stringent economic measure, the poverty profile of Nigeria has spiralled from 28 percent of Nigerians that lived in poverty in 1980 to $46.3 \%$ in 1985 . In 1992, Nigeria's poverty rate reduced slightly to $42.7 \%$ and rose astronomically to $66 \%$ in 1996 and then soared to $70 \%$ in 1999 and galloped to $84.4 \%$ in 2004 , and eventually to $112,518,507$ or $69 \%$ of the estimated 140 million Nigerian population (as at 2006) going by the relative poverty measurement in 2010. In terms of absolute poverty, the $54.7 \%$ poverty profile of Nigeria in 2004 rose to 60.9 per cent (or 99, 284,512 Nigerians) in 2010. Going by dollar-per-day poverty measurement, Nigeria's poverty level stood at 70.4 per cent in 2010 while in terms of subjective poverty measurement, it increased from 75.7 per cent in 2004 to 93.9 per cent in 2010 with a projection by the National Bureau of Statistics that Nigeria's poverty profile would jump to about 71.5 per cent in relative poverty, 61.9 per cent in absolute poverty and 62.8 per cent in dollar-per-day poverty measurements (The Report of National Bureau of Statistics, 2012).

This deep and pervasive poverty trend in Nigeria has made the poor to be not only in disarray but also restless. Thus while the situation created the generation of economic migrants and brain drain (Agbu 2008:3), other victims of poverty in Nigeria have become despondent and resigned to fate by trooping to Pentecostal Christian churches imported from South America and radical Islamic faith imported from Saudi Arabia and Iran (Nwakanma 2007: 16). Meanwhile, the majority of the victims of the deteriorating poverty conditions in Nigeria have simply resorted to high profile crimes such as hostage-taking for ransom, human trafficking, armed robbery, cyber-crimes, insurgency, etc. This deepening social malaise generated a huge threat to the legitimacy of government and inexorably propelled the government of President Olusegun Obasanjo to in 2003 incorporate the poverty alleviation programme in the National Economic Empowerment and Development Strategies (NEEDS). Understandably, this perhaps was an attempt to forestall the Karl Marx's prophecy of class war from becoming a reality. 
After all, as J.F Kennedy rightly observed "if the poor cannot sleep because they are hungry, the rich cannot sleep because the poor are awake" (Akinyemi, 1991: 25).

\section{Assessing the implementation of poverty reduction programme in Enugu State}

The National Economic Empowerment and Development Strategy (NEEDS) which encapsulates the National Poverty Alleviation Programme (NAPEP) among others is indeed a national policy instrument for the reduction of poverty and sensitizing development in the country. As a result, the NEEDS is implemented in the thirty-six states of the federation as the State Economic Empowerment and Development Strategy (SEEDS) and at the seven hundred and seventy four local government councils in Nigeria as the Local Economic Empowerment and Development Strategy (LEEDS). With its main focus on the creation of wealth, creation of employment, reduction of poverty and the general reorientation of values, the implementation of the programme kicked off nationwide in 2003 (National Planning Commission, 2004:5).

Located in the South Eastern part of Nigeria, Enugu State was carved out of Anambra State on August 27, 1991. It shares borders with Abia and Imo States to the South, Ebonyi State to the East, Benue State to the North East, Kogi State to the North West, and Anambra State to the West. With a land area of about 7627.20 Square Kilometres, Enugu State has seventeen (17) Local Government Areas grouped into three senatorial zones namely, Enugu East, Enugu West and Enugu North. Each Local Government Area in the State is sub-divided into Wards and Communities led by traditional rulers and his cabinet as well as the Town Union Governments (ENSG, 2012: 3). Based on the 2006 Census, the State has a population of about 3,257,298 comprising 1,624,202 males and $1,633,096$ females. It is predominantly Igbo speaking and predominantly rural and agrarian with substantial proportion of its working population engaged in farming, services, trading, local art and craft. However, trading followed by services is the predominant occupation in the urban areas with a small proportion of the population also engaging in manufacturing activities.

In compliance with the NEEDS guidelines towards the realization of the Millennium Development Goals (MDGs), a Ministry of Human Capital Development and Poverty 
78 Africa's Public Service Delivery \& Performance Review

Reduction Strategy was accordingly established in Enugu State, not only to coordinate and supervise but also to provide a pedestal for systemic, integrated inter-sectoral approach to the implementation of the poverty reduction programme. The Ministry anchors the implementation of the poverty alleviation programme on Conditional Cash Transfer (CCT) scheme. This basically comprises the Monthly Sustenance Allowance (MSA) and Business Startup Grant (BSG). As the name quickly suggests, the MSA is a monthly guaranteed income of six thousand naira (N6000) disbursed bi-monthly to the targeted household beneficiaries while the BSG is a guaranteed investment grant of twelve thousand naira $(\mathrm{N} 12,000)$ disbursed to the targeted individual beneficiaries to set up an enterprise after undergoing the State government sponsored 12 months training in vocational and skills acquisition. For even spread of beneficiaries and effective implementation, the Ministry of Human Capital Development and Poverty Reduction has a Programme Implementation and Coordination outfit that co-ordinates all the activities of the different agencies involved in the implementation process.

The Programme is designed to cover ten communities from each of the ten LGAs in the State per a year. This implies that a total of one hundred (100) out of the four hundred and seventy three (473) communities in the State are marked out to benefit from the exercise each year. More so, nine households from each of the selected 100 communities are the actual beneficiaries after satisfying the following qualifying eligibility criteria of being:

i. Poor female-headed households with basic education children;

ii. Poor aged-headed households with basic education children (with the main income-owner of over 60 years of age);

iii. Poor widows-headed households with basic education age children;

iv. Households-headed by the physically challenged [e.g. lepers] with basic education age children;

v. Households headed by VVF patients and people living with HIV/AIDs [PLWHAs], TB as well as orphans and vulnerable children with basic education age;

vi. (Households) with a trainable adult [ENSG, 2012:9]. 
Others considered to benefit from the scheme are the unemployed graduates and rural farmers.

In line with this modality, this study carried out a survey of the implementation on nine households from the ten communities of the selected ten L.G.As of the State for study. Accordingly, a random sampling of the views of the beneficiaries was carried out through interview method. Three out of the nine beneficiaries selected from the three senatorial districts were interviewed. The Local Governments are as follows: Igbo Etiti, Udenu, Uzo-Uwani, Nkanu West, Isi-Uzo, Aninri, Enugu North, Enugu South, Ezeagu and Udi. In all, this results in a total of nine hundred (900) household beneficiaries of both the MSA and BSG each year, which this study used as a focal point for assessing the implementation of poverty reduction programme in the State.

The communities from where the selected household beneficiaries were drawn from were found to have on ground adequate infrastructures (supply) that are prerequisite for the effective implementation of the programme such as:

i. functioning primary health centre or basic health dispensary;

ii. functioning primary school;

iii. functioning secondary school up to JSS3 (basic education level);

iv. community based committees;

v. formal/informal skill and vocational training centres within the locality.

These are complemented by the availability of the sundry community based donor supported supply side interventions such as the National FADAMA Development programme (NFDP), the Local Empowerment and Environmental Management Programme (LEEMP), Community Social and Development Programme (CSDP), and the National Directorate of Employment (NDE) skill and vocational training centres.

Between 2004 and 2012 for which records are available, the study shows that under the Monthly Sustenance Allowance of the Conditional Cash Transfer scheme, a total of eight thousand, one hundred households spread across the 473 communities that make up the 17 LGAs of Enugu State have benefited from the scheme. Out of this number, $84.4 \%$ or 6840 households participated but $35.5 \%$ enrolled their children in primary 1 up to JSS3, as well as accessed the free medical care including investing the grant in income 


\section{Africa's Public Service Delivery \& Performance Review}

generating enterprises while $64.5 \%$ household beneficiaries did not comply with the school attendance and health conditionality.

With regards to the Business Start-up Grants (BSG), the same number of 8,100 qualified households with trainable adults benefitted. Out of this number, thirty-five percent $(35 \%)$ or 2,835 beneficiaries were trained on vocational skills while sixty-five percent $(65 \%)$ of the beneficiaries did not participate in the training. Overall, majority of the beneficiaries of both the CCT Monthly Sustenance Allowance and Business Startup Grant in Enugu State Nigeria did not comply with the respective conditions of education, health and vocational training, implying that there was little or no significant impact of the implementation of poverty alleviation programme in Enugu State. Table 1 below provides a graphic summary of the impact of the implementation of poverty alleviation programme in the State.

Table 1: Distribution of Participants and Outcomes of Conditional Cash Transfer (CCT) in Enugu State between 2004 and 2012

\begin{tabular}{|l|l|l|l|l|}
\hline Year & $\begin{array}{l}\text { Projected annual } \\
\text { beneficiaries }\end{array}$ & $\begin{array}{l}\text { Frequency of actual } \\
\text { beneficiaries }\end{array}$ & $\begin{array}{l}\text { Percentage of actual } \\
\text { beneficiaries }\end{array}$ & $\begin{array}{l}\text { Percentage } \\
\text { outcome }\end{array}$ \\
\hline 2004 & 900 & 900 & 100 & 40.1 \\
\hline 2005 & 900 & 840 & 93.3 & 32.7 \\
\hline 2006 & 900 & 800 & 88.8 & 33.8 \\
\hline 2007 & 900 & 780 & 86.7 & 33.9 \\
\hline 2008 & 900 & 870 & 96.6 & 34.5 \\
\hline 2009 & 900 & 900 & 100 & 39.4 \\
\hline 2010 & 900 & 400 & 44.4 & 27.8 \\
\hline 2011 & 900 & 650 & 72.2 & 35.2 \\
\hline 2012 & 900 & 700 & 77.7 & 34.9 \\
\hline Total & $\mathbf{8 1 0 0}$ & $\mathbf{6 8 4 0}$ & $\mathbf{8 4 . 4}$ & $\mathbf{3 4 . 7}$ \\
\hline
\end{tabular}

Source: Household Survey 2013

Abundant empirical studies exist to affirm the positive impact of the implementation of poverty alleviation programme in parts of the world (Goldberg, 2005; Khander, 2003; Akinlo \& Oni, 2012). For instance, Asemelash (2003) and Alemu (2006) both share the view that poverty alleviation through conditional cash transfer helps to increase the 
Poverty Reduction Program in Nigeria: An Assessment of its Implementation in Enugu State 81

income for the poor as well as increase their access to better schools and medical facilities. Equally, Littlefield and Hashemi (2003) and Nwigwe, Omonoma and Okoruwa (2012) reinforced this position in their separate studies when they pointed out that microcredit creates the path out of the poverty and hunger of the poor by not only protecting, diversifying and increasing their source of income but also by increasing their self employment opportunities as well as improving the standard of their living condition and credit worthiness.

However, the contrast seems the case in Enugu State. For instance, findings reveal that only $34.7 \%$ out of the 6840 of the beneficiaries of the Conditional Cash Transfer (CCT) scheme under the platform of poverty alleviation programme in Enugu State agree to how the twin process of monthly Sustenance Allowance (MSA) and Business Startup Grant (BSG) have helped tremendously in reducing their poverty especially through the creation of self employment opportunities and availing them of the wherewithal to engage in small businesses for daily income. According to Mrs Ugonne Eze, a poor widow heading a household of three basic education age children who benefited from the programme in 2008, she was able to acquire vocational training in food, catering and event management and has since after the training become flourishing in that enterprise to the extent that her household can now afford three square meals daily, while her children are well progressing in their schools. Also Okay Nnamani of Akpugo community in Nkanu West LGA of Enugu State, a beneficiary of Business Startup Grant in 2009, noted that his social and economic life has been enhanced with his trade in GSM phone repairs, and sale of cellular phone accessories at Otigba by Fire Service junction, Enugu. He further stated that he has now enrolled at the Institute of Management and Technology (IMT) as a student of Electrical/Electronic Engineering as well as being the breadwinner of his family of five headed by his aged mother. Other beneficiaries interviewed (Benjamin Akor from Okpanku community in Aniri LGA now engaged in vulcanizing at Zik's Avenue Uwani Enugu; Ephraim Ozor from Aku community in Igbo Etiti LGA, an automobile electrician at Coal Camp Enugu; Ebere Omeje, a hairdresser from Ezimo community in Udenu LGA; Sunday Nwamuoh, a carpenter and upholstery maker based at Onwudiwe by Edozie street Uwani Enugu; Ifeanyi Duru, a welder and fabricator at Agbani road Enugu, etc) all re-echo the testimony that they have jumped 
out of poverty and hunger through the Business Startup Grant of the Conditional Cash Transfer toward alleviating their poverty.

Generally, the findings reveal that most beneficiaries of the CCT scheme in Enugu State invested their grants on different vocational skills and small scale enterprises such as hairdressing, fabrication and welding; others include vulcanizing, carpentry and upholstery making, GSM repairs, even planning and management, food and catering services, sale of GSM recharge cards, GSM accessories, etc. Invariably, only a few numbers of beneficiaries of the CCT scheme from the Enugu State poverty alleviation programme between 2004 and 2012 have been able to turn around their poverty status. In any case, $64.5 \%$ of the beneficiaries interviewed gave contrasting report about its impact on their social and economic life. To this category of beneficiaries, the measure is not only inadequate but also being subverted by the implementation officials. Others even claim that they were not aware of the scheme and therefore did not participate; yet they were included as beneficiaries of the scheme. Thus Emeka Ikpeama from Iwolo-Oye in Ezeagu LGA who participated in the exercise under the Business Startup Grant in 2012 adduced that he diverted the grant to consumption and to defray debts. Similarly, Madam Eucharia Onu from Ikem community in Isi-Uzo LGA reported that the Monthly Sustenance Allowance she accessed in 2009 was a drop in the ocean of her household's problems since her aliment hampered her engagement in any viable or income generating venture coupled with the fact that her two little children were too tender to be helpful. Thus there was no remarkable improvement in their standard of living.

Pius Akor from Nkpologu community and Theresa Ezeugwu from Uvuru community both in Uzo-Uwani L. G A. argued that the scheme was a hoax as no citizen of the Local Government Area is aware or had ever participated in the Conditional Cash Transfer scheme of the Enugu State Poverty Alleviation Programme. This tends to reinforce the contention of many (Karnani, 2007; Mahajan, 2005; Pollin, 2007; Hulme \& Mosley 1996) that grant or microcredit is a necessary but not a sufficient condition for poverty reduction. This is premised on the ground that apart from the initiative being hijacked by the privileged members of the society that are not poor and have sustainable income, some targeted members of the society who eventually benefit from the scheme are bereft of basic formal education, experience and, most importantly, vocational skills to judiciously utilize the grant in sustainable income generating enterprises. Abundant empirical evidence exists in Enugu State to buttress this position, especially in Uzo- 
Uwani, Aninri, Igbo-Etiti, Oji-River, Nkanu East, Awgu and Igboeze South Local Government Areas.

Specifically, however, the fact that 62.5 per cent of the estimated 3,267,837 population of Enugu State based on the 2006 census are still groaning under the heavy weight of poverty in spite of the poverty alleviation initiatives is a sad testament of the inefficient and ineffective implementation of the whole gamut of the poverty reduction package by the successive governments (See Table 2 at the Appendix for details). This is logical fallout of many factors working in combination not only to bedraggle the drive at poverty reduction in the State. These include:

Policy inconsistency: One of the major obstacles to poverty reduction efforts in Enugu state is the arbitrary discontinuation of programmes by successive governments. Taking Nigeria as whole, this has been a source of concern. Thus, even when policies are well-conceived and with good intention to benefit the masses, once the incumbent that initiated the policy or project leaves office, the successor would quickly and arbitrarily abandon the inherited programme. For instance, the poverty alleviation/eradication programme encapsulated in the National Economic Empowerment and Development Strategy (NEEDS) that occupied the front burner of the former government of Chief Olusegun Obasanjo was quietly swept under the carpet of his successor late Alhaji Umaru Musa Yar'Adua's Seven Point Agenda for vision 2020; just as President Goodluck Jonathan who stepped into his shoes brushed aside the Seven Point Agenda he inherited and replaced it with his own pet agenda christened as the Transformation Agenda. In Enugu State, similar action was taken by the incumbent against some laudable poverty alleviation schemes initiated by his predecessor such as the School Meal Plus. In fact, all the previous poverty alleviation measures put in place by the former Governor Chimaroke Nnamani of Enugu State have been consigned to oblivion and replaced with the incumbent Governor Sullivan Chime's "4 Point Agenda".

Another policy inconsistency of the government is the incessant disruption and truncation of small and medium-scale enterprises through the demolition of "illegal structures" (ironically approved or ignored by the same government at the outset) and the banning of the operation of commercial motorcycles popularly known as Okada. Majority of the people in this trade are the poor who feed (live) from hand to mouth 
and have immediate and extended families to fend for. They also include the artisans and roadside traders who depend on the repairing of the motorcycles and GSM phones or the selling of the motorcycle spare parts to earn a living. They obviously engage in the petty business not because they choose to but because their state of living disallows them from affording the high cost of renting spacious shops and outfits. They improvise with kiosks and containers along the sideways of the major roads in the town to attract easy patronages. Notwithstanding this fact however, the government would all of a sudden declare the kiosks and containers as illegal structures and demolish them. As a matter of fact, this amounts to the contradiction of the poverty alleviation initiative that espouses self-employment and wealth creation. If not a contradiction, how can the government explain such action? True, the government cannot be touting poverty reduction strategy and wealth creation, and at the same time be destroying the business of the self-employed small-scale entrepreneurs who generate wealth through sales of recharge cards and GSM phone accessories. This was the case under the Obasanjo government (2003-2007) in Abuja, Federal Capital Territory that has come to be known as the "El-Rufai demolition" - a derivation from the name of the FCT Minister, Mallam Nasri El-Rufai, who carried out the demolition exercise. Similar measures are still taking place in Enugu State where commercial motorcycle operation was banned in 2012 and many structures including the Old Park are being demolished on the ground of urban renewal.

An examination of the policies shows that they are the same and thus raises the curious question of why discontinuing initial programmes. This is more disturbing against the backdrop of the fact that the abandonment will impinge on effective monitoring and evaluation and consequently lead to the diversion and mismanagement of public funds already mapped out for the project in the national budget.

Mismanagement and Profligacy: Corruption has been widely acknowledged as an integral part of Nigeria's political culture. Thus, it has permeated the entire social life of the country and particularly pervades in the high places. For instance, rather than deploy resources judiciously to reduce poverty, the political leaders are engaged in mismanagement and diversion of the public funds. Above all, instead of empowering the people to generate wealth, the Nigerian political leaders indulge in giving out pittance as cash gift and food items to the poor while diverting the surplus balance from the budgeted amount to their private accounts. However, it suffices to point out that the 
mismanagement and diversion of the public fund mapped out to reduce poverty in parts of the country by the governing elites is motivated by their desire to widen the gap between the rich and the poor. This is because the existence of the poor serves the enlightened interest of having a ready pool of low wage labourers who are available to perform the "dirty work" that rich people are unwilling to perform (Offiong 2001:125). Most importantly, poverty provides the politicians with available "raw materials" for touts, political thugery, and electoral fraud. Thus it would translate to a class suicide for the rich to encourage and not undermine the poverty reduction strategy.

\section{Conclusion}

The essence of government is the provision of a good life to the people. Any government that ignores this invariably places its legitimacy on tenterhooks and may eventually collapse. Therefore the initiation of poverty reduction programmes is an obligation of the government; its implementation is therefore mandatory. The poverty alleviation programme in Enugu State is poorly implemented and this explains why there are larger numbers of the citizens who are still helpless. The government has to stamp its authority on the implementation process to ensure that the fifth columnists and the subversive elements undermining the implementation of the programme are identified and made to face the wrath of the law. Meanwhile, the current strategy of creating jobs through the provision of vocational tutelage for the unskilled should be extended to all the communities in Enugu State and complemented with the evolution of a proper education system that would chase the millions of kids hawking sachet water and groundnuts off the streets of Enugu State. 
86 Africa's Public Service Delivery \& Performance Review

\section{List of References}

- Agbaegbu, T. 2012. "Poverty: The Rampaging Scourge in the North" in Newswatch, April 23, 12-13.

- Agbu, O. 1997. Economic Reforms and their Aftermath in Nigeria," Nigerian Forum, vol. 18 Nos. 4-5, May/June (81).

- Agbu, O. 2008. "Revisiting corruption and human trafficking in Nigeria. Any Progress? Nigerian Forum, vol. 29, Nos3-4, March/April (7).

- Akinlo, A. E. and Olufemi Isaac Oni 2012. "Impact of Micro-Finance on Poverty Alleviation in Ondo State, Nigeria", Australian Journal of Business and Management Research. Vol. 2, No. 09 (31-37) December'

- Akinyemi, A. B. 1991. "In Search of a New World Order". Being the 1991 NSIA Lecture delivered on 5 August, 1991 at the Nigerian Institute of International Affairs.

- Appadorai, A 2003. The Substance of Politics. Oxford: University Press.

- Asemelash, 2003."The Impact of Microfinance in Ethiopia: The Case of DCSI in Ganta Afeshun Woreda of Eastern Tigray. M. A. Thesis, Department of RLDS,AAU."

- Chime, I. S. 2011. "A New Pledge to do More". An Inaugural Address on the Occasion of his Swearing-in for $2^{\text {nd }}$ Term as Governor, Enugu State.

- De Jouvenal, B. 1951. Ethics of Redistribution. Cambridge: Cambridge University Press.

- Eric, J. H. 1968. "Poverty" in International Ecyclopeadia of the Social Sciences. New York: McGraw-Hill.

- Enugu State Government of Nigeria 2011. "Programme Implementation Manual for the 2011 Conditional Cash Transfer (CCT) Programme in Enugu State, Nigeria." Enugu: Ministry of Human Development and Poverty Reduction.

- Goldberg, N. 2005. Measuring the Impact of Microfinance: Taking Stock in what we know. USA: Grameen Foundation.

- Hobbes, T. 1651. (Ed. Pogson Smith). Leviathan. Oxford University Press.

- Hulme, D. and Mosley, P. 1996. Finance against Poverty. London: Routledge. 
- Karnani, A. 2007. "Microfinance Misses its Mark". Stanford Social Innovation Review. Summer.

- Khandker, S. R. 2003. Microfinance and Poverty: Evidence Using Panel Data from Bangladesh . Retrieved from http//:econ.worldbank.org

- Lampman, R. J. 1951. Ends and Means of Reducing Income Poverty. Chicago: Markham Publishing Company.

- Littlefield, E., M., J. and Hashemi, S. 2003. Is Microfinance an Effective Strategy to reach the Millennium Development Goals? CGAP Focus Note, Washington DC.

- Mahajan, V. 2005. "From Microcredit to Livelihood Finance". Economic and Political Weekly, October 8.

- Marx, K. 1977. A Contribution to the Critique of Political Economy. Moscow: Progress Publishers

- National Bureau of Statistics 2012. "Report on the Harmonized Nigeria Living Standard Surveys". February 13.

- National Planning Commission 2004; 2005. National Economic Empowerment and Development Strategy (NEEDS). Abuja: National Planning Commission, Nigeria.

- Newswatch 2012. "Poverty in the North: Who's to Blame?" April 23 (12-20).

- Nwaigwe, C. A. Omonoma, B. T. and Okoruwa, V. O. 2012. "Microfinance and Poverty Reduction in Nigeria: A Critical Assessment". Australian Journal of Business and Management Research 2(3), 33-40.

- Nwakanma, O. 2007. "Social security is national security" in Sunday Vanguard, 12 August (16).

- Odunuga, Y. 2012. North versus South: The Politics of Poverty in The Nation on Sunday, March 4 (15).

- Offiong, D. A. 2001. Globalization: Post- Neodependency and Poverty in Africa. Enugu: Fourth Dimension Publishers.

- Pollin, R. 2007. "Microcredit: False Hopes and Real Possibilities". Foreign Policy Focus, http//:www.fpif.org/fpiftxt/432. 


\section{Africa's Public Service Delivery \& Performance Review}

- Rein, M. 1971. "Problems in the Definition and Measurement of Poverty" in H. Townsend, The Poverty Establishment. New York: Praeger.

- Sabine, G. H. and T. L. Thorson 1973. A History of Political Theory $4^{\text {th }}$ Edition. New Dheli: Dryden Press.

- Sani, S. 2012 "Poverty Alleviation Programme Is a Mirage", Newswatch, April 23.

- Sautter, H. 1990. "Economic and Ethnic Aspects of the International Debt Problem" Nigeria Institute of International Affairs Lecture Series No.62 (7).

- Sen, A. 1981. .Poverty and Famine: An Essay on Entitlement and Deprivation. Oxford: Clarendon Press.

- Spencer, H. 1940. The Man versus the State. Caldwell, Ida: Caxton.

- Sunmonu, H. A. 1990. Strategies for Development in Africa: An African Worker's View", Nigerian Institute of International Affairs Lecture Series, No 60. (8).

- The Nation. March 4, 2012. (25-26)

- Toyo, E.1989, "The Prospects of African Development and Self Reliance in the 1990s." Nigeria Institute of International Affairs Lecture Series No.53 (20-21).

- Umunna, U.M. 2008. Urban Administration: An Overview. Onitsha: Hallmark Press.

- Yusuf, I. A. 2012. "Rising GDP, Rising Poverty" The Nation on Sunday, March 4(57).

\section{Appendix}

Table 2. Distribution of Poverty in Nigeria

\begin{tabular}{|l|l|l|l|}
\hline S/No & State & Population & Poverty Profile \\
\hline 1 & Kano & $9,401,288$ & 65.6 \\
\hline 2 & Lagos & $9,113,605$ & 48.6 \\
\hline 3 & Kaduna & $6,113,503$ & 61.5 \\
\hline 4 & Kastina & $5,801,584$ & 74.5 \\
\hline 5 & Oyo & $5,580,894$ & 51.8 \\
\hline 6 & Rivers & $5,198,716$ & 50.4 \\
\hline 7 & Bauchi & $4,653,066$ & 73.0 \\
\hline 8 & Jigawa & $4,361,002$ & 74.1 \\
\hline 9 & Benue & $4,253,641$ & 67.1 \\
\hline 10 & Anambra & $4,177,641$ & 56.8 \\
\hline 11 & Borno & $4,171,104$ & 55.1 \\
\hline 12 & Delta & $4,112,445$ & 63.3 \\
\hline
\end{tabular}




\begin{tabular}{|l|l|l|l|}
\hline 13 & Imo & $3,927,563$ & 50.5 \\
\hline 14 & Niger & $3,954,772$ & 33.8 \\
\hline 15 & A/ibom & $3,902,051$ & 53.7 \\
\hline 16 & Ogun & $3,751,140$ & 62.3 \\
\hline 17 & Sokoto & $3,702,676$ & 81.2 \\
\hline 18 & Ondo & $3,460,877$ & 45.7 \\
\hline 19 & Osun & $3,416,959$ & 37.8 \\
\hline 20 & Kogi & $3,314,043$ & 67.1 \\
\hline 21 & Zamfara & $3,278,873$ & 70.8 \\
\hline 22 & Enugu & $3,267,837$ & 62.5 \\
\hline 23 & Kebbi & $3,256,541$ & 72.0 \\
\hline 24 & Edo & $3,233,366$ & 65.6 \\
\hline 25 & Plateau & $3,206,531$ & 74.1 \\
\hline 26 & Adamawa & $3,178,950$ & 74.2 \\
\hline 27 & C /Rivers & $2,882,988$ & 52.9 \\
\hline 28 & Abia & $2,845,370$ & 57.4 \\
\hline 29 & Ekiti & $2,398,357$ & 52.4 \\
\hline 30 & Kwara & $2,365,357$ & 61.8 \\
\hline 31 & Gombe & $2,365,040$ & 74.2 \\
\hline 32 & Yobe & $2,321,339$ & 73.8 \\
\hline 33 & Taraba & $2,294,800$ & 68.9 \\
\hline 34 & Ebonyi & $2,176,947$ & 73.6 \\
\hline 35 & Nasarawa & $1,869,377$ & 60.4 \\
\hline 36 & Bayelsa & $1,704,515$ & 47.0 \\
\hline
\end{tabular}

Sources: National Bureau of Statistics, 2012; National Population Commission, 2006

\section{AUTHORS' CONTACT:}

OMEMMA, Dilichukwu A.

Department of Political Science Caritas University

Enugu, Nigeria

E-mail: diliomemma@yahoo.com

\section{OKAFOR, Chukwuemeka}

School of Public Administration

University of Fort Hare

South Africa

Email: cokafor@ufh.ac.za 